小動物臨床家のための臨床検査機器とその応用 (III)

血液検査の機器

吉田 化*

獣医臨床の場で，臨床検査の占める重みが増すととも に，諸検査の設備を併設した病院が多くなった．反面， ほとんどを院外検查に頼る傾向も見受けられる．一般に は，発病経過中の一時期に当たる初診時に得た検体の情 報を教科書的・文献的正常値と比較して, 病勢判定の一 助とする場合が少なくないと思われる.しかし、いわゆる 正常值は報告者により, また, 条件 (品種·性別, 年龄, 飼養環境, 検查方法, 機器の種類, さらには採材の時刻 や季節等々) によって差異があり得る. したがって, 数 值のみの比較では危険を伴う。また，検体の鮮度によっ ても数值が異なることがある.いわゆる, 正常值は 1 つの 参考としてとら学るべきであって，むしろ新鮮な検体に よる検查を反復して, その成績の推移から, 病勢や治療 効果を判定することの方が意義が深い。一般にいら血液 検查とは, 血液の細胞学的検查を意味しており, その目 的は, (1) 貧血の有無とその種類, (2) 炎症性, 中毒性 疾患の有無, (3) 血液寄生虫類の有無, (4) 血液病の誘 因となる個体の素質や白血病の有無等々を確認すること にある. 時には望診, 触診, 聴診, 打診等の臨床診断で 得た情報に対する客観的裏付けであり, 確定診断の根拠 ともなる. 血液検查の検体はすべて全血のままで使用す るため, 取り分け速やかに処理し, 信頼度の高い結果を 得て, 他の諸検査の成績とともに診断に役立てることが 望ましい，そのような意味から，ここでは，院外検查に 頼らず, 院内で容易に処理可能な, 従来から応用されて きた方法を中心に取り上げることにした。

\section{1. 赤血球数および白血球数}

小動物を対象とした場合には血球計算板法と自動血球 計算機による方法がある.1回に何 10 , 何100の検体を処 理するのでなければ, 計算板法はきわめて安易な方法で ある.

\section{1) 赤血球数算定の器材と方法}

赤血球用メランジュール（希釈用ピペット）, 計算板 (改良型ノイバゥェルが使いやすい)，Hayem 試液（希 釈液, 市販), 他にカウンター, 顕微鏡, メランジュール, 微洗浄器具等.

* 日本大学農獣医学部（神奈川県藤沢市亀井野 1866）
(1) 採血直後の全血，または凝固阻止血液をメランジ ュールの 0.5 の目盛りまで吸引し, 外壁に付着した血液 をよく拭きとる.

(2) ガラス小容器に移した試液を 101 の目盛りまで静 かに吸引, メランジュール付属の吸引用ゴム管で両端を しっかり押光, 希採室（メランジュールの膨大部）を中 心に, シェーカーを振るようによく振盪して, 血液の均 一懸濁液とする.

(3) メランジュールの先端から, $2 \sim 3$ 滴を捨て, 計 算板の計算室に希釈血液を流し込む。

(4) $2 \sim 3$ 分待って, 赤血球が沈下したところで, 200 〜 400 倍の顕微鏡下で算定する.

\section{〔計 算 室と算 定〕}

数種類の計算板が市販されているが，原則的にはどれ も同等の機能を持っている.

赤血球計算室は, 1 辺 $1 \mathrm{~mm}$ の正方形を絽横 20 等分 して, 1 辺が $50 \mu$ の正方形 (小区画) 400 個からなり, この小区画 16 個 $(4 \times 4)$ が集まった正方形を中区画と 呼ぶ．中区画が集合して計算室を作り，中央に位置して いる(図 $1:$ この板では中区画が 25 カ所ある).

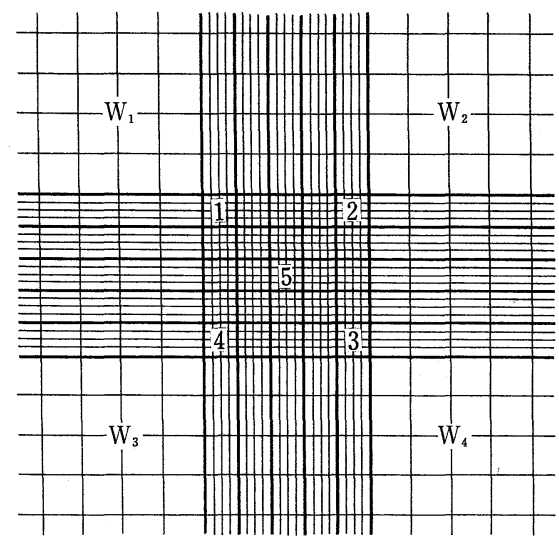

図 1 改良型 Neubauer 血球計算板の区画: 中 央が赤血球計算室（例えば 1 5 のように 5 カ所で算定する), $W_{1} \sim W_{4}$ は白血球計 算室（1 枚の計算板にこの区画が 2 カ所あ るので, 上を赤血球, 下を白血球とすれば, 1 回で 1 頭分を処理することができる） 
技術

辺が隣接しない中区画の 5 カ所に分散する赤血球を数 え, この総和に $10^{4}$ を剩ずれば $1 \mathrm{~mm}^{3}$ 中の赤血球数が 得られる.すなわち，今，中区画 5 力所の和が 543 だと すれば, この数は $1 \mathrm{~mm}^{2}$ の 5 分の 1 (小区画 400 カ所 中の 80 力所）で，計算室の深さ $0.1 \mathrm{~mm}$ の範囲にあっ て，200 倍に希釈された血液中の全赤血球数であるから, 式は次のようになる.

赤血球数 $/ 1 \mathrm{~mm}^{3}=543 \times \frac{400}{80} \times 10 \times 200=543 \times 10^{4}$

2) 白血 球数 算 定の器材と方法

白血球数の算定は赤血球数の算定と同様に行う.

白血球用メランジュール, 計算板 (赤血球と共通),

Türk 試液 (市販).

(1) 採血直後または凝固阻止した全血をメランジュ ールの 1.0 の目盛りまで吸引する.

(2) 小容器に移した試液を 11 の目盛りまで吸引し, 赤血球の場合と同様によく振盪する.

(3) 計算室に希釈血液を流し込む.

(4) $2 \sim 3$ 分待って, 白血球が沈下したら算定する.

\section{〔計 算 室 と 算 定〕}

白血球の計算室は赤血球の計算室の 4 隅にあり, 1 辺 が $1 \mathrm{~mm}$ で, 縦横 4 等分され, 各々 $250 \mu$ の正方形 16 個からなる（図 1 ）. 4 室のすべての白血球を数光，4で 割って算数平均值を求め, これに 100 を剩ずれば, 血液 $1 \mathrm{~mm}^{3}$ 中の白血球数が得られる. 寸なわち，4 力所の総 和が 330 とすれば，この数は， $1 \mathrm{~mm}^{2}$ が 4 力所であるか ら, $1 \mathrm{~mm}^{2}$ では 82.5 となる. 計算室の深さは $0.1 \mathrm{~mm}$ であるから 10 倍，また希釈液によって 10 倍に希釈さ れているから，式は次のよらになる.

白血球数 $/ 1 \mathrm{~mm}^{3}=82.5 \times(10 \times 10)=8,250$

\section{3）血 球計 算板 法の特 質}

器材は比較的安価で, 操作にも収納にも場所をとらな い.しかし，いかなる検査でもその操作を䛊れば，得ら れた情報の信頼度は失われる.この方法も慣れればきわ めて簡単で, 血球計算の基本である. 反面, 次の事項に 注意が必要である.

(1) メランジュールでの血液の吸引は量を正確に，と くに凝固阻止を施した血液は吸引前によく振った均一液 であること。

(2) 希釈液の吸引も正確に，気泡が入らないように行 う. 振盪は血球が希釈室から目盛りのある管部にまで散 らないよらに。

(3) よく振盪して，血球の均一懸濁液としてから計算 室に流し込む. 量が不足したり，多過ぎて計算室の脇の 溝に流れ落ちないように.

(4) 算定はカウンターを用いて行い. 計算室の検液が 乾かないらちに終了する.

以上のことが守られないと，求められる数值は過大に も過少にもなり得る. いっぽう, 被検血液の赤血球数が
講㭫

著しく増加している場合には，血液を 0.5 以下の適切と 思われる目盛りまで吸引し，著しい減少では，逆に 1.0 まで吸引して, 希釈倍数を加減する. 白血球が増多の場 合も同様に処理できる.ただし，これは白血球の減少で は応用できない.このメランジュールの取り扱いに慣れ ると，好酸球や血小板の算定も試薬が異なるだけできわ めて容易に応用可能となる. 最近では，メランジェール の操作を簡易にしたディスポーザブルの血液希釈用ピペ ット (Unopette ${ }^{\circledR)}$ が市販されている。

\section{2. 血小 板}

血小板数の増加は骨髄機能の妄進傾向の際に認められ る. すなわち, 失血性・鉄欠乏性貧血, 溶血性貧血, 急 性伝染病の極期等. 減少は一般に骨髄機能が減退する場 合で, 白血球の減少を伴う. 急性白血病, 悪性貧血, 肝 硬変等にみられる.

血小板の算定には直接法と間接法がある.

\section{1） Rees-Ecker 法（直接法）}

赤血球計算と同様に，全血を用いて血小板を直接算定 する方法で，同時に赤血球数と網状赤血球の算定が可能 な方法である.

器材と方法 : 赤血球用メランジュール, 血球計算板, Rees-Ecker 試液 (市販).

(1) 被検血液は採血直後または EDTA で凝固阻止さ れた全血.

(2) Rees-Ecker 液 (希釈液) をメランジュールの目盛 の 0.5〜1.0の範囲まで吸い上げて，ただちに吹き出す. これは粘着性に富む血小板が管内壁に付着するのを防ぐ ため。

(3) 被検血液を目盛の 0.5 まで吸引し，次いで希釈液 を101まで吸引して 2〜5 分間よく振盪する.

(4) 赤血球の計算と同様に計算室に希釈した液を流し 込さ.

(5) 血小板が沈下するまで $10 〜 15$ 分間待つ. この時, 計算室の液が乾かないように注意する（例えば，湿った 濾紙かガーゼを敷いた容器に計算板を入れておく).

(6) 乾燥系対物レンズの強拡大下（400～600 倍）で, 赤血球計算室の小区画 400 力所 $\left(1 \mathrm{~mm}^{2}\right)$ のすべての血 小板を算定する（血小板の増加が著明な時は赤血球数と 同様に扱ら).

(7) 算定した血小板数 (n) を 2,000 倍すれば $1 \mathrm{~mm}^{3}$ 中の血小板数が得られる. 式は次のと抢りである.

血小板数 $/ 1 \mathrm{~mm}^{3}=\mathrm{n} \times(10 \times 200)=\mathrm{n} \times 2,000$

計算室の深さは $0.1 \mathrm{~mm}$ ，したがって 10 倍，また血 液の希釈倍数は 200 である.

視野にみられる血小板は淡青紫色に染色され， $1 \sim 2 \mu$ の小体, 赤血球は染色されずに淡黄色を呈し, 網状赤血 球の網状顆粒は黒青色に染色されるので, 容易に識別で 
きる.

\section{2） Fonio 法 (間接法)}

(1) 新鮮全血と $14 \%$ 硫酸マグネシウム溶液を $1: 3$ の 割合で混合する.

(2) 血液塗抹標本と同様にスライドグラスに叙布して 十分に空気中で乾燥する.

(3) メチルアルコールで 5 分間固定の後, 形ど拈りの ギムザ染色を施す.

(4) 鏡検によって赤血球 1,000 個を数卉, これと同視 野内の血小板 $(\mathrm{P})$ を算定する. また，これとは別に赤血 球数を算定して打く. 求める $1 \mathrm{~mm}^{3}$ 中の血小板数は次 の式で得られる.

$$
\text { 血小板数 } / 1 \mathrm{~mm}^{3}=\frac{\mathrm{P} \times \text { 赤血球数 }}{1,000}
$$

\section{3. ヘマトクリット $(\mathbf{H t}$ 值) または PGV}

全血に対する赤血球容積比で,最近では PCV (Packed cell volume) \%で表現する方が馴じみがよい. 代表的な 方法には Wintrobe 法と毛細管法がある.

1) Wintrobe 法

(1) 凝固阻止した全血をWintrobe 管の目盛 10 まで, 管底から毛細ピペットでてい称いに注入する(約 $1 \mathrm{~m} l$ 使 用).

(2) 次いで，遠心分離 $3,000 \mathrm{rpm} 30$ 分（または， $10,000 \mathrm{rpm} 3$ 分, 7,500 rpm 5 分).

(3) 遠心後の赤血球層の高さを管壁の目盛りで読みと り, 全量に対する比を求める. 血漿表面が 10.0 で, 赤 血球層が 3.5 であれば $35 \%$, 血漿面が 9.8 で赤血球層 が 3.5 であれば,

$$
\mathrm{Ht}(\mathrm{PCV})=\frac{3.5 \times 100}{9.8}=35.71 ， 35.7 \% \text { となる. }
$$

この方法は血液を多量に必要とするのが, 小動物での 難点とい方よう.

\section{2）毛 細 管 法}

(1) 専用の毛細管（内径 $1.8 \mathrm{~mm}$, 長さ $75 \mathrm{~mm}$ ) 飞 はヘパリン処理とプレインの 2 種類ある. 前者は新鮮全 血を, 後者では凝固阻止した全血を管全長の $2 / 3$ 程度ま で吸引する。

(2) 管の一端を専用のパテで封ずる.

(3) 遠心分離 ( $\mathrm{Ht}$ 用高速遠心器を使用する. 多種の 国産品があり，あまり高価ではない)，11,000 rpm 5 分. 低回転（2,000 ならびに 5,000 rpm）で安定してから段 階的に回転数を上げると, 管の破損もなく機器も長持ち する. $11,000 \mathrm{rpm}$ になるまでに約 1 分をかけるので, タ イマーのセットに注意する.

(4) 遠心後, 付属の計測器で測定值 (\%)が求められる. 毛細管上清の血漿は, 例えば血漿総蛋白量の測定, ま た血球層の直上部では弱拡大の鏡検で, 犬糸状虫の $\mathrm{mf}$ が確認できるなど，他の目的で利用しやすい。

\section{4. ヘモグロビン}

ヘモグロビン $(\mathrm{Hb})$ の定量には，Hb を塩酸へマチン に変光て比色する方法, 血液中の鉄を測定して Hb に換 算する方法怙よびシアンメトへモグロビン法はどがある が，㛜密な意味で正確に $\mathrm{Hb}$ を測定できる方法はない。 最近は，シアンメトへモグロビンやアザイトメトへモグ ロビンを光電比色計あるいは分光光度計によって測定す る方法が定着してきた(例, Bio-Dynamics 社製 Chemtek system). 従来からある Sahli-小宮法は比色法で, 個人的 な主観による判定の誤差が生じやすいが, 器具も操作も 簡単で, しかも出先でも容易に結果が得られる利点があ る.

\section{Sahli-小宮法}

器材と方法: Sahli 血色素計, 試薬は 0.1 規定塩酸 （局方塩酸を 60 倍に希釈するだけでよい）.

(1) 付属の試験管の $10 \%$ の目盛りまで試薬を入れる （あまり正確でなくてもよい).

(2) 付属の $0.02 \mathrm{~m} l$ ピペットで正確に血液（新鮮血， または凝固阻止血）を取り，試験管の中に泡を生じない ように数回呼吸を繰り返して洗い込む.

(3) 試験管の外壁から指ではじくように内容をよく混 和して, $30 \sim 60^{\circ} \mathrm{C}$ の温湯に 15 分間直立放置する（液は $\mathrm{Hb}$ が塩酸へマチンに変化して茶褐色を呈する).

(4) 試験管に付属のガラス棒で攪拌しながら水を加兄 て標準着色ガラス ( $1 \%$ 塩酸へマチングリセリンと同色) の色調と一致するまで希釈する（個人的誤差はこの時生 じやすい).

(5) 試験管壁の目盛りで液面の高さを読む。管壁には $\%$ と $\mathrm{g} / \mathrm{d} l$ の 2 と敊りの目盛りがあるが， $\mathrm{g} / \mathrm{d} l$ の表現を 利用した方がよい.

\section{5. 赤 血 球 指 数}

生体に扝ける貧血の有無を知る目的では, 既述の赤血 球数, $\mathrm{Hb}$ 值抢よび $\mathrm{Ht}(\mathrm{PCV})$ 值の 3 者の数值をそれぞ れ単独に入手すればよい。しかし，貧血の種類を知る目 的では， 3 者の相互関係を比較する必要がある. この関 係を赤血球指数と呼んでいる.

\section{1）平均赤血球容皘 〔Mean Corpuscular Volume (MCV)]}

赤血球 1 個の平均容積であるから, $1 \mathrm{~mm}^{3}$ 中の赤血球 数で, 同一体積中の PCV を除せばよい. 例爷ば，PCV $35 \%$, 赤血球数 $500 \times 10^{4} / \mathrm{mm}^{3}$ とすると, $1 \mathrm{~mm}^{3}=10^{9} \mu^{3}$ であるから,

$$
\begin{aligned}
\mathrm{MCV} & =\frac{\mathrm{PCV}(\%) \times 10^{9}}{\text { 赤血球数 }}=\frac{\frac{35}{100} \times 10^{9}}{500 \times 10^{4}}=\frac{35 \times 10^{7}}{5 \times 10^{6}}=\frac{350}{5} \\
& =70 \mu^{3}
\end{aligned}
$$

すなわち, 赤血球 1 個の平均容積は $70 \mu^{3}$ となる. 
技術講座

\section{2）平均赤血球血色素量〔Mean Corpuscular Hemoglobin (MGH)]}

赤血球 1 個当たりの血色素重量である. $1 \mathrm{~mm}^{3}$ 中の赤 血球数で同一体積中の $\mathrm{Hb}$ 重量を除せばよい。例方ば, $\mathrm{Hb} 12 \mathrm{~g} / \mathrm{d} l$, 赤血球数 $500 \times 10^{4} / \mathrm{mm}^{3}$ とすれば, $\mathrm{Hb} 12 \mathrm{~g}$ $/ \mathrm{d} l$ は $12 \mathrm{~g} / 100 \mathrm{~m} l$ であり, 赤血球数も同じ体積の 100 $\mathrm{m} l$ に換算するか, 逆に $\mathrm{Hb} 12 \mathrm{~g} / \mathrm{d} l$ を赤血球数と同体積 の $1 \mathrm{~mm}^{3}$ 換算しなければならない。

$$
\begin{aligned}
\mathrm{MCH} & =\frac{\mathrm{Hb} \mathrm{g} / \mathrm{d} l}{\text { 赤血球数 } / \mathrm{d} l}=\frac{12 \times 10^{12}}{100(\mathrm{~d} l) \times 1,000\left(\mathrm{~mm}^{3}\right) \times 500 \times 10^{4}} \\
& =\frac{120}{5}=24 \mathrm{pg} *
\end{aligned}
$$

すなわち，赤血球 1 個当たりの $\mathrm{Hb}$ 重量は $24 \mathrm{pg}$ とな る.

* $\mathrm{pg}=$ Picogram $\left(10^{-12} \mathrm{~g}, 1 \mathrm{~g}\right.$ の 100 万分の 1 の 100 万分の 1 の単位を表わす)

\section{3）平均赤血球血色素濃度 (Mean Corpuscular \\ Hemoglobin Goncentration (MCHC)]}

赤血球容積 $(\mathrm{PCV})$ に対する $\mathrm{Hb}$ の重量比であり, 普 通は \%(w/v\%) で表わす。例光ば, 前例と同じに PCV $35 \%, \mathrm{Hb} 12 \mathrm{~g} / \mathrm{d} l$ とすれば，この場合も前二者と同様に 同一体積に換算して值を求める.

$$
\mathrm{MCHC}=\frac{\mathrm{Hb}(\mathrm{g} / 100 \mathrm{~m} l)}{\mathrm{PCV}(\mathrm{m} l / 100 \mathrm{~m} l)} \times 100=\frac{12}{35} \times 100=34.2857 \cdots
$$

すなわち，MCHC は $34.3 \%$ となる.

七トの赤血球指数は, 赤血球数 500 万 $/ \mathrm{mm}^{3}, \mathrm{Hb}$ 值 $16 \mathrm{~g} / \mathrm{d} l, \mathrm{Ht}(\mathrm{PCV})$ 值 $45 \%$ を基準にして, 各指数の正 常值を 1 とし, 患者の実測值を比率で比較することに決 めている. しかし, 獣医学領域では, この規定がないか ら，患畜から得られた各指数は報告者の測定条件をよく 吟味した上で，比較検討を加党ることが肝要である。ま た，当然算定基礎となる赤血球数， $\mathrm{Hb}$ 值， $\mathrm{PCV}$ の誤差 はそのまま各指数に反映することを知らなければならな い.

\section{6. 赤血球浸透圧（または赤血球抵抗）}

段階的な低張食塩液を用いて，赤血球浸透圧抵抗を調 へ，溶血性貧血の診断没役立てる. 赤血球の細胞膜は柔 軟であるが弾力性に乏しい，したがって表面積に対する 容積比が小さい注ど，つまり赤血球細胞が小さいものは 大きいるのより破れやすく溶血を起こしやすい，光電比 色計を用いる Parpart 法が優れているが，操作が簡単な Ribière 法の变法が便利である.
〔器 材 と 方 法〕

(1) $1.0 \%$ 食塩溶液 (高純度の試薬 $\mathrm{NaCl} 1.0 \mathrm{~g}$ を水に 溶かして全量を $100 \mathrm{~m} l$ とする）を試薬として調製する.

(2) 小試験管を 15 本程度（12 20 本位）用意し，前 述の $\mathrm{NaCl}$ 試薬から， $0.02 \%$ 等差で段階的濃度の食塩 液（各 $1 \sim 2 \mathrm{ml}$ ）を作製し，濃度のラベルを貼る。濃度 の範囲は $0.60 \sim 0.30 \%$ 程度で, 症例によって多少上下 そ異なる。

(3) 採血直後の新鮮静脈血を針先から 1 滴ずつ各管に 滴下し，よく振温した後，1時間室温に直立静置する.

(4) 1 時間後に溶血の状態を判定する.

(5) 食塩水が淡く赤染した最初の管が溶血開始で，そ の濃度を最小抵抗といい，管底に赤血球がまったく認め られない最初の管が完全溶血で，その濃度を最大抵抗と いう，不明の場合には遠心分離する。 また，最小抵抗と 最大抵抗の濃度差を抵抗幅と呼んでいる。

\begin{tabular}{ccc}
\hline & 最大抵抗 $(\%)$ & 最小抵抗 \\
\hline 犬 & 0.50 & 0.32 \\
猫 & 0.72 & 0.46 \\
ヒト & 0.44 & 0.32 \\
\hline
\end{tabular}

以上のような記載があり,ヒトに比べると犬や猫では, 濃度がやや高く，抵抗幅が大きい傾向がある。

$$
\text { むす び }
$$

以上飞記した“血液検查”に加えて, 重要な項目は血 液の塗抹標本の鏡検に上る血球細胞の形態的観察であ る.

すなわち，赤血球の形態や染色の状態，および白血球 百分比である．これらは，赤血球汉り込まれるいわゆ る血液原虫性疾患の確認, 貧血の種類, 病勢や予後の判 定などに有用で，数值による各成績の裏付けとなる資料 が得られる，とかく，標本の作製や鏡検（とくに白血球 の百分比では少なくとも200 個以上，できれば500〜 1,000 個を数兄るので）が面倒だと思われがちである が，その意義は大きく，またこれる慣れればきわめて簡 単である. 紙面の都合で標本作製の詳述は避けるが，身 近な参考図書(後記)に従って習熟することを勧めたい。

『参考図書としては下記のほか，多数見受けられる.』

高橋 貢, ほか: 家畜の臨床検查, 医菌薬出版.

大石 勇 : 犬の内科診断学, 日本獣医師会.

金井 泉, 活か：臨床検查法提要, 金原出版。

中村良一: 家畜内科彮断学, 養賢堂. 